\title{
Article
}

\section{Enforcing Marine Environmental Law in China: Some New Measures}

Zou, Keyuan and Wang, Jiayi

Available at http://clok.uclan.ac.uk/29545/

Zou, Keyuan ORCID: 0000-0002-2868-4948 and Wang, Jiayi (2019) Enforcing Marine Environmental Law in China: Some New Measures. Chinese Journal of International Law, 18 (1). pp. 193-207. ISSN 1540-1650

It is advisable to refer to the publisher's version if you intend to cite from the work. https://doi.org/10.1093/chinesejil/jmz006

For more information about UCLan's research in this area go to

http://www.uclan.ac.uk/researchgroups/ and search for < name of research Group>.

For information about Research generally at UCLan please go to http://www.uclan.ac.uk/research/

All outputs in CLoK are protected by Intellectual Property Rights law, including Copyright law. Copyright, IPR and Moral Rights for the works on this site are retained by the individual authors and/or other copyright owners. Terms and conditions for use of this material are defined in the policies page.

\section{CLoK}

Central Lancashire online Knowledge www.clok.uclan.ac.uk

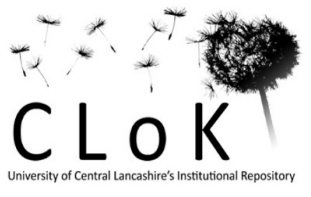




\title{
Current Developments
}

\author{
Enforcing Marine Environmental Law in China: Some New \\ Measures
}

\author{
ZOU Keyuan* and WANG Jiayi**
}

1. In recent years, China has adopted and/or revised a series of laws and regulations concerning the protection of the marine environment. This paper aims to provide an overview of the recent developments in this respect and to highlight some new and innovative law-making efforts in China ${ }^{1}$ to further strengthen the marine environmental protection and sustainable use of marine natural resources.

\section{Establishing a new fundamental system of marine ecological red line}

2. In order to meet the new requirements for the protection of marine ecological environment, China has sped up the development of domestic laws and regulations. The Law on Marine Environment Protection of the People's Republic of China (LMEP) was revised and became effective on 5 November 2017. The revised LMEP adds a new clause in the general provisions, which states that "the State sets ecological protection red lines in key marine ecological functional zones, eco-sensitive areas and fragile zones, and strictly implements protection."'2 Thus, the marine ecological red line

* Deputy Editor-in-Chief of this Journal.

** Guanghua Law School, Zhejiang University, Hangzhou, China. This paper is part of a research project funded by China's National Social Sciences Foundation (18VHQ002).

1 This short paper does not intend to cover every aspect of recent developments of marine environmental protection in China. For example, it does not mention marine environmental contingency plans, and for a relevant reference, see Keyuan Zou and Jiayi Wang, "China's Practice in Marine Environmental Contingency Planning", in: Anastasia Telesetsky, Warwick Gullett and Seokwoo Lee (eds.), Marine Pollution Contingency Planning: State Practice in Asia Pacific States (Brill, 2017), 62-82. 
(MERL) has been made as a fundamental system for marine environmental protection, ${ }^{3}$ and its implementation has borne stronger binding force. ${ }^{4}$

3. The MERL is a major institutional innovation in China. In terms of spatial planning, it refers to the geographical boundary line of the areas with special important ecological functions ${ }^{5}$ that should have mandatory strict protection. ${ }^{6}$ The essential objective of the MERL is to identify the important marine ecological functional areas, marine ecological fragile areas and marine ecological sensitive areas, then to further subdivide them into prohibited and restricted development zones respectively according to ecological characteristics and management objectives. As an approach of marine spatial planning, the MERL is the concretization of the protection of marine ecological space under the guidance of the National Marine

Marine Environment Protection Law Art. 3.

3 The SOA interprets the revision of the Marine Environmental Protection Law of the People's Republic of China, available at: (www.scio.gov.cn/xwfbh/gbwxwfbh/xwfbh/hyj/Document/1546466/15 46466.htm).

4 The Chinese government first introduced the concept of the ecological red line in the Opinions of the State Council on Priorities of Strengthening Environmental Protection, issued in 2011; after then, the revised Environment Protection Law of the People's Republic of China, which came into effective in 2015, proposed the requirement to draw all kinds of ecological red lines. The marine ecological red line was officially introduced by the SOA in 2016 with the two leading binding documents: Opinions on Establishing and Implementing the System of the Marine Ecological Red Lines and the Technical Guide for Demarcation of Marine Ecological Red Lines. However, the legal status of the MERL was not clearly defined in these documents, thus causing ambiguity in practice. Now, the MERL is confirmed by the LEMP which is a national law with high legal hierarchy and which can prevail over all the administrative and local regulations and rules if there is a conflict.

5 The areas with special important ecological functions include areas with the functions of water conservation, biodiversity conservation, soil and water conservation, windbreak and sand fixation, coastal ecological stability and other ecologically sensitive and fragile regions which are prone to soil erosion, land desertification, rocky desertification and salinization.

6 Opinions on Defining and Protecting Ecological Redlines, issued by the Party Central Committee and the State Council in February 2017, available at: (www.gov.cn/zhengce/2017-02/07/content_5166291.htm). 
Functional Zoning. ${ }^{7}$ In terms of management planning, the MERL refers to the management indicator control line, ${ }^{8}$ and the management control indicators for the MERL include area, natural shoreline retention, island natural coastline retention, the quality of sea water and pollutant discharge reduction'; thus the MERL can be regarded as a bottom line of marine ecological environmental management.

4. The whole process of the implementation of the MERL is very complicated. The local governments should firstly identify the marine red line zones, with the consideration of connection and coordination with Marine Functional Zones (MFZ) and other relevant planning, then formulate the corresponding classified and graded access control measures, according to the different classifications of red line zones (see Figure 1). The MERL provides a more comprehensive evaluation and spatial integrity, and it can strengthen the existing MFZ at an ecosystem level. ${ }^{10}$ The revised LMEP gives clear legal authority and binding force to the implementation of the MERL. Therefore, MFZ combined with the MERL constitutes a fundamental top-down marine spatial planning system in China, which makes larger marine reserves possible, and promotes the integration between economic development and ecological environmental protection. It is required that more than $30 \%$ of the coastal provincial administrative areas

7 S.X. Wang, The Marine Ecological Red Line of Shandong Province (in Chinese) (Beijing: Ocean Press 2017), 378.

8 SOA, Technical Guide for Demarcation of Marine Ecological Red Lines, April 2016.

9 When the coastal governments delineate the MERL, the control indicators should be fixed according to the ecological environmental situation, socioeconomic situation and other relevant planning. Take the MERL of Bohai Sea as an example. The control indicators include that: the retention rate of Bohai shoreline is not less than $40 \%$; the proportion area of the MERL zones in the Bohai Sea area under Shandong province is not less than $40 \%$; by 2020, in the MERL zones, $100 \%$ of the pollutants discharged from direct drain outlets must meet the acceptable standard, and the total amount of land-based pollutants entering into the sea must be reduced by $10-15 \%$; and by 2020 , in the MERL zones, $80 \%$ of waters should meet acceptable water quality targets. See Wang, above n.7, at 8.

10 W.H. Lu, J. Liu, X.Q. Xiang, et.al, 'A comparison of marine spatial planning approaches in China: Marine functional zoning and the marine ecological red line', Marine Policy, Vol.62 (2015), 94-101. 
should be designated as MERL areas. ${ }^{11}$ Since the control indictors of the MERL are directly related to marine biodiversity, species conservation is the key factor of evaluating ecological importance when identifying the MERL areas. A recent research on the MERL of Liaoning province indicates that the evaluation of high ecological importance is dominated by species conservation, accounting for $90.2 \%$ of the total conservation areas. ${ }^{12}$ Thus, there is no doubt the implementation of the MERL can promote marine biodiversity conservation at a higher level.

Figure 1: Technical Flow Chart of Marine Ecological Red Lines

11 See SOA, Opinions on the Establishing and Implementing the System of the Marine Ecological Red Lines, available at: (www.gov.cn/xinwen/201606/16/content_5082772.htm).

12 C.S. Wang, G.Y. Sun, and L.J. Dang, 'Identifying Ecological Red Lines: A Case Study of the Coast in Liaoning Province', Sustainability, Vol.7 (2015), 9475. 


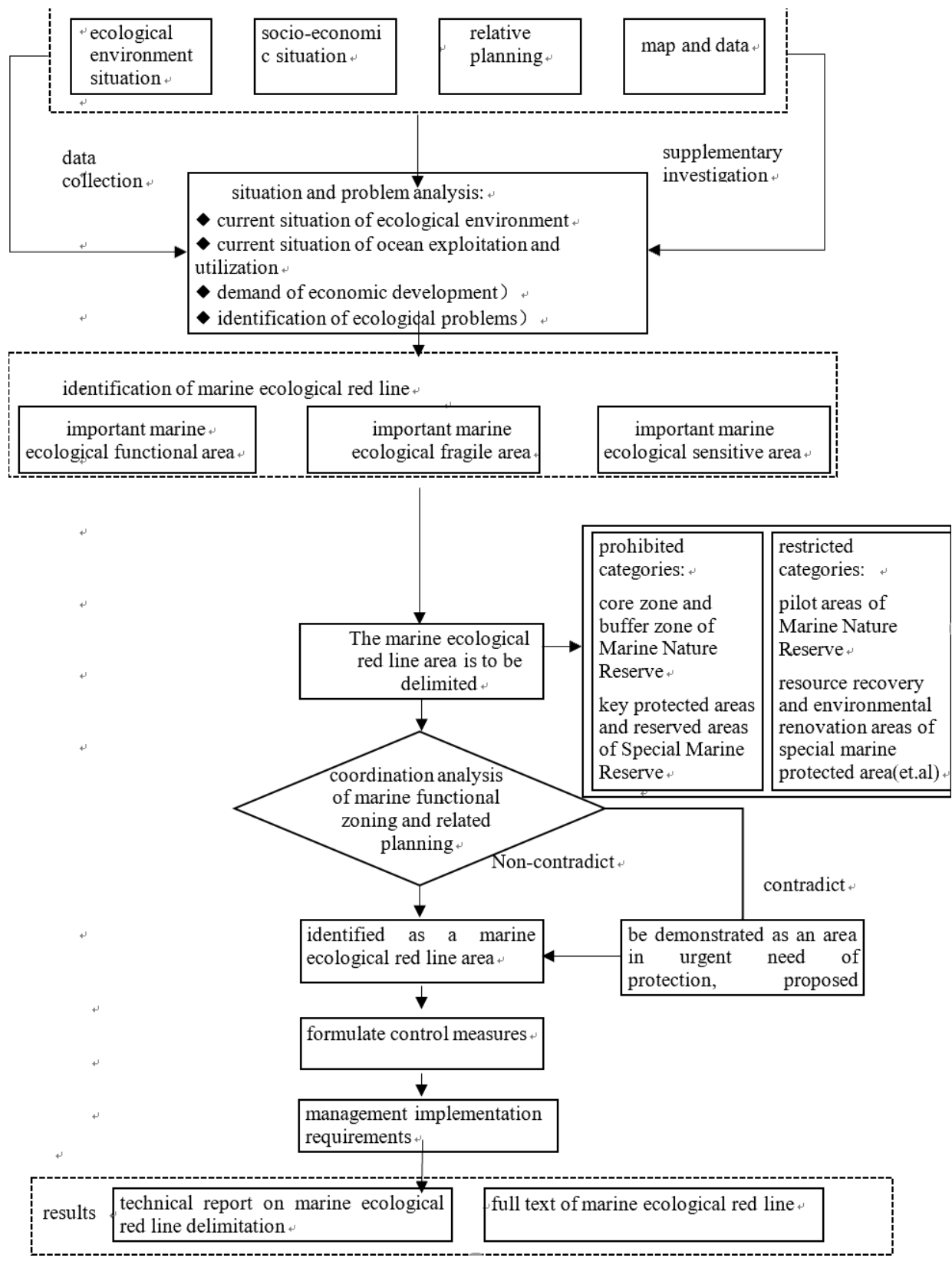

Source: State Oceanic Administration, Technical Guide for Demarcation of Marine Ecological Red Lines, April 2016. 


\section{Strengthening the legal system of marine ecological compensation}

5. The loss of marine biodiversity is a complex problem which needs to be addressed by scientific policy, integrated environmental management, appropriate laws and regulations as well as an adequate judicial system. The ecological compensation system with strong legal support and supervision established by the revised $\mathrm{LMEP}^{13}$ can be regarded as a positive response to this policy.

6. The marine ecological compensation mechanism is an economic incentive measure to coordinate ocean resources exploitation and marine ecological protection. It usually includes two types of compensation: Marine Ecological Protective Compensation (MEPC) and Marine Ecological Damage Compensation (MEDC). ${ }^{14}$ MEPC can enhance the government's responsibility for ecological protection, while MEDC can effectively constrain the individuals and enterprises involved in marine exploitation and utilization activities. ${ }^{15}$ Therefore, the marine ecological compensation mechanism is an effective approach to achieving the conservation and sustainable use of marine biodiversity. China introduced the marine ecological compensation mechanism in the 1990s, and has since carried it out in establishing a marine paid use system and ecological compensation measures of fishery and seawater pollution. ${ }^{16}$ However, the mechanism has

13 Article 24 of the revised LMEP provides that "The state shall establish and improve a compensation system for marine ecological protection."

14 J.M. Li and X. Yang, 'Research review of marine eco-compensation', Ocean Development and Management (in Chinese), No. 8 (2015), 85-91. MEPC refers to the government's expenditure on the restoration of the marine ecosystem and the compensation for the ecological protectors, while MEDC concerns the ecological loss caused by exploitation and utilization activities, see Y.H. Jiang, J.W. Zhang, K.L. Chen, et al. 'Moving towards a systematic marine eco-compensation mechanism in China: policy, practice and strategy', Ocean and Coastal Management, Vol.169 (2019), at 11.

15 The MEDC guarantees the marine biological loss caused by human activities would be compensated properly, and the liability burden can push the developers to comply with due diligence and protect the ecological environment.

16 Q.Z. Qu, S.B. Tsai, M.X. Tang, et.al. 'Marine Ecological Environment Management Based on Ecological Compensation Mechanisms', Sustainability, Vol.8 (2016), 1267. 
not functioned well due to insufficient legal support. The legal status, the procedures as well as the authority's responsibilities need further clarification by national law to guarantee effective ecological compensation.

7. Having realized the importance of the legal mechanism for ecological compensation, the revised LMEP defines ecological compensation as a fundamental means for marine environmental protection. ${ }^{17}$ Article 89 stipulates that a person who caused damage to the marine environment shall compensate for the loss; where the damage to marine ecology, marine resources and marine protected areas causes great loss to the State, the department exercising the right to administer and supervise the marine environment shall claim damages on behalf of the State against the responsible person. ${ }^{18}$ However, this is just a general provision, and when put into practice, more detailed provisions would be needed.

8. On 29 December 2017, the Supreme People's Court issued a judicial interpretation on handling cases concerning compensation disputes over marine natural resources and environmental damage, which became effective on 15 January 2018. ${ }^{19}$ It contains 13 provisions, and mainly addresses the issue of how to implement the principled provision of Article 89 of LMEP. The new judicial interpretation clarifies the nature of claims for the damage to marine natural resources and ecological environment, which solved the dilemma caused by the conflict of laws in the application. ${ }^{20}$ It also detailed the substantive and procedural rules of

17 'The State Oceanic Administration interprets the revision of the Marine Environmental Protection Law of the People's Republic of China', available

(www.scio.gov.cn/xwfbh/gbwxwfbh/xwfbh/hyj/Document/1546466/15

46466.htm).

18 Marine Environment Protection Law Art. 87.

19 Supreme People's Court on Handling Cases concerning Compensation Disputes over Marine Natural Resources and Environmental Damage (Judicial Interpretation, [2017] 23), available at: (www.court.gov.cn/zixunxiangqing-76502.html). China's constitutional law endows the supreme judicial authority with the right to judicial interpretation. The judicial interpretation by the Supreme People's Court has legal effect, and the lower courts can directly cite the interpretation in their judgments. The judicial interpretation is a quasi-source of legislation, which is purported to fill the legislative lacuna.

20 The lawsuit for ecological compensation, as an environmental tort litigation 
ecological compensation, which provides legal certainty. Article 2 of this judicial interpretation provides that where a party concerned submits a lawsuit for ecological compensation, it shall be under the jurisdiction of the maritime court of the place where the damage occurred, or where the injury outcome occurred, or where the preventive measures were taken. ${ }^{21}$ The purpose of determining these three jurisdictional connecting factors is to put all disputes that actually or potentially affect China's jurisdictional seas under the jurisdiction of China's maritime courts. The compensation includes the cost for preventive measures, restoration expenses, loss during restoration and investigation expenses, ${ }^{22}$ which fully matches the technical standards for damage assessment formulated by the SOA. ${ }^{23}$ This judicial interpretation provides judicial guarantee for the implementation of relevant standards, and makes the ecological damage compensation better functioning. In view of the complexity of the causes of marine pollution and the fact that the assessment mechanism is not yet perfect, ${ }^{24}$ it also

and environmental civil public interest litigation, also belongs to the scope of the application of the Supreme People's Court's Interpretation on Several Issues concerning the Application of Law in the Trial of Environmental Civil Public Interest and the Supreme People's Court's Interpretation on Several Issues concerning the Application of Law in the Trial of Disputes over Liability for Environment Torts. However, compensation proceedings for the damage to marine natural resources and ecological environment shall apply the Interpretation on Handling Cases concerning Compensation Disputes over Marine Natural Resources and Environmental Damage; but where there are no applicable provisions in this interpretation to find, the other two judicial interpretations would apply.

21 Supreme People's Court on Handling Cases concerning Compensation Disputes over Marine Natural Resources and Environmental Damage, Art.2.

22 Ibid.

23 The Technical Guide to Marine Ecological Damage Assessment issued by the SOA in August 2013 stipulates that the calculation content of marine ecological damage is: the cost of preventive measures such as pollution removal and damage reduction; the loss of marine living resources and marine environmental capacity during the recovery period; the cost of marine ecological restoration; testing, evaluation and other reasonable expenses.

24 S.M. Wang and X.H. Yu, 'The understanding and application of the regulation for judging cases concerning compensation disputes over marine 
provides two alternative methods for identifying restoration costs and loss during restoration to overcome the difficulties of burden of proof in reality. When it is difficult to define the restoration costs and loss during restoration, the court may reasonably determine the amount of compensation for the loss according to the benefits obtained by the person responsible for the damage or the reduced expenses paid for pollution prevention and control. ${ }^{25}$ If the income or expenses specified in the proceedings cannot be ascertained, the court may rationally determine the amount of compensation with reference to the average income of business operators of the same category in the same region and the average pollution prevention and control expenses by relevant statistical data of the government departments or other evidence. ${ }^{26}$ The general rules of loss identification combined with two alternative methods set up three "defensive lines" for the protection of the marine ecological environment, ${ }^{27}$ and ensure that the damaged would get reasonable compensation as much as possible.

9. In general, the revised LMEP and the Supreme People's Court's judicial interpretation promote the judicialization of the marine ecological compensation system, and help courts exercise better judicial function in marine biodiversity conservation. However, those developments mainly concern the MEDC, and as to the MEPC, there is still lack of specific guidance for the governments to carry out ecological restoration as well as compensation for the protectors. Since the MEPC is the safeguard measure of the MERL system, it needs to be enhanced in future. ${ }^{28}$

\section{Establishing a green tax system supporting marine pollution control}

natural resources and environmental damage', The People's Judicature (Application) (in Chinese), No.7 (2018), 25.

25 Supreme People's Court on Handling Cases concerning Compensation Disputes over Marine Natural Resources and Environmental Damage, Art. 9.

26 Ibid.

$27 \quad$ Wang and $\mathrm{Yu}$, above n.24.

28 Ecological restoration is one of the basic contents of the ecological red line system, and in the prohibited and restricted areas, economic development is constrained due to ecological protection, thus those regions should be properly compensated. 
10. Marine pollution is regarded as a direct threat to the survival of the diversified marine life. ${ }^{29}$ Dumping, oil spills, sewage discharge, solid wastes and other forms of pollution cause the deterioration of the marine ecosystem and the loss of marine biodiversity. Being aware of this, China has currently adopted stricter regulations and substantial measures to prevent pollution at sea.

11. On 1 January 2018, the Environmental Protection Tax Law (EPTL), which had attracted much attention, came into effect. ${ }^{30}$ With the implementation of the EPTL, the previous "pollution discharge fee" is abolished and replaced with the "environmental protection tax". It is an important step towards environmental protection and ecological civilization. Under the EPTL, enterprises, public institutions and other producers or operators that directly discharge taxable pollutants are defined as taxpayers and shall pay the environmental protection tax. ${ }^{31}$ Taxable pollutants include atmospheric pollutants, water pollutants, solid wastes and construction site noise. ${ }^{32}$ The environmental protection taxes are levied on both land and sea discharges. The general principle of taxation is that more discharges incur more taxes, and the tax rates vary according to the hazardous level of pollutants. This new tax system will encourage the enterprises to reduce discharges of pollutants and develop green energy consumption. That will have a positive impact on the prevention of hazardous and solid wastes from entering into the sea. Compared with the "pollution discharge fee", the EPTL creates more incentives for polluters to reduce marine pollution, and adds a new tax relief category under which the taxpayers will receive a $25 \%$ reduction of payable tax where the concentration value of the taxable air pollutants or water pollutants discharged is lower than $30 \%$ of the pollutant discharge standards as prescribed by the State or the local area. ${ }^{33}$

29 A. Farmer, Managing Environmental Pollution (London: Routledge, 2013), 156.

30 The law was passed at the 25th Session of the 12th National People's Congress in December 2016.

31 Environmental Protection Tax Law, Art. 2.

32 Environmental Protection Tax Law, Art. 3.

33 Environmental Protection Tax Law, Art. 13. The previous "pollution discharge fee" only had one category of fee relief that the payers would get a $50 \%$ reduction when they lowered the concentration of discharge of atmospheric or water pollutants by half of the national or provincial 
In order to incentivize the local government to supervise and monitor polluters as well as to better integrate environment protection into economic development, the EPTL stipulates that the environmental protection tax will be part of local tax revenues, and the local governments have the authority to set the tax rates within the range defined by the central government. ${ }^{34}$ As to the coastal provinces and cities, the tax collection will become financial support for local governments to conduct marine environment protection projects and measures.

12. In addition, the EPTL also sets a specific provision with regard to marine projects, which provides that "for the taxpayers engaging in marine projects to discharge taxable pollutants, the specific measures for the filing of an environmental protection tax shall be formulated by the competent tax department of the State Council in conjunction with the ecological and environmental department of the State Council." 35 Thus, the tax rates of marine projects have been set forth in the Measures for Filing and Collection of Environmental Protection Tax Related to Marine Projects, ${ }^{36}$ which became effective on 1 January 2018. According to it, the enterprises and public institutions engaged in the exploration for offshore oil and natural gas and discharging taxable pollutants into the inland waters, territorial seas, contiguous zones, exclusive economic zones and continental shelves shall pay the tax, ${ }^{37}$ and the tax rates are calculated differently by the classification of atmosphere pollutants, waste water and solid waste discharge. 38 This measure will greatly strengthen the environmental

standards.

34 Environmental Protection Tax Law, Art. 6. It is reported that the regions that have heavy environmental problems, such as Beijing and Tianjin, have adopted higher rates.

35 Environmental Protection Tax Law, Art. 22.

36 The measures were jointly issued by SOA.

37 The Measures for Filing and Collection of Environmental Protection Tax related to Marine Projects, Clause 2.

38 As atmospheric pollutants are discharged into the marine environment, EPT payable shall be levied on the top three pollutants which are ranked according to the pollution equivalent weight that is converted from the quantity of taxable pollutants discharged from each drain or discharged directly into the marine environment; waste water is discharged into the marine environment due to production activities and engine room sewage, mud and scraps created by drilling and domestic sewage, EPT shall be 
protection awareness of marine resources developers, and intensify their pollution abatement responsibilities, all of which can promote conservation of the marine ecosystem and marine biodiversity.

\section{Amending the regulations on solid waste control and water pollution}

13. Solid wastes might contain hazardous chemicals that can endanger marine wildlife and damage sea plants. ${ }^{39}$ Therefore, preventing solid wastes from entering into the sea is currently another important approach taken by the Chinese government to aid marine biodiversity conservation.

14. From 2017, China started to adjust its regulations on solid waste imports. The Implementation Plan for the Reform of the Import Management System of Solid Waste was adopted at the 34th Meeting of the Central Leading Group for Deepening Overall Reform, ${ }^{40}$ by which solid wastes that cause great environmental damage would be forbidden from import by the end of 2017, and the imported solid wastes that can be replaced by domestic resources should be phased out by the end of 2019 .

15. From 1 January 2018, China started implementing the ban of imports of 24 specific wastes in four categories (see Table 1 for categories). ${ }^{41}$ This new regulation is a positive response to ecological civilization. It would push solid waste management toward higher-value and lower-pollution raw materials, and dramatically reduce the volume of mismanaged solid wastes entering into the sea.

Table 1: Catalogue of Solid Wastes Forbidden to Import

calculated and levied on the basis of the pollution equivalent weight converted from the quantity of taxable pollutants discharged; solid wastes are discharged into the sea water, EPT shall be calculated and levied on the quantity discharged.

39 C.H. Sujatha, V.B. Pratheesh, and Y.T. Hung, 'River and Lake Pollution', in: L.K. Wang, Y.T. Hung, and N.K. Shammas (eds.), Handbook of Environment and Waste Management: Air and Water Pollution Control (World SCI., 2012), 998.

40 See: (www.mep.gov.cn/xxgk/hjyw/201704/t20170419_411714.shtml).

41 On 18 July 2017, China sent a notice to the WTO, stating that by the end of 2017, China would ban imports of 24 specific wastes. 


\begin{tabular}{|l|lll|}
\hline Product Category & HS Code & \\
\hline Vanadium slag & 2619000021 & 2620999019 \\
& 2619000029 & 2620999011 \\
\hline Plastic waste & 3915100000 & 3915200000 & 3915300000 \\
& 3915901000 & 3915909000 & \\
\hline Unsorted waste paper & 4707900090 & & \\
& & & \\
\hline Waste textile materials & 5103109090 & 5103209090 & 5103300090 \\
& 5104009090 & 5202100000 & 5202910000 \\
& 5202990000 & 5505100000 & 5505200000 \\
& 6310100010 & 6310900010 & \\
\hline
\end{tabular}

Source: Prepared by the authors by comparing the new Catalogue of Solid Wastes Forbidden to Import with the previous one.

16. Besides controlling the solid wastes entering into the sea, China also pays attention to water pollution which might have a negative effect on the marine environment. At the start of 2018, China enacted the newly revised Water Pollution Prevention and Control Law, ${ }^{42}$ which introduces the river chief system to address pollution in coastlines and offshore areas. Under the river chief system, the responsibility of local government and transparent governance were enhanced. It defines the leading officials at all government levels (province, city, county, township) as appointed chiefs, with comprehensive responsibility for pollution prevention, resource protection and ecological restoration. ${ }^{43}$ The municipal and county governments shall formulate plans for achieving goals within a specified period, and annually report to the people's congress at the corresponding level on the implementation of the plan and make it public. The achievement of water

42 The Water Pollution Prevention and Control Law was amended for the second time according to the Decision on Amending the Water Pollution Prevention and Control Law of the People's Republic of China as adopted at the 28th Session of the Standing Committee of the Twelfth National People's Congress on 27 June 2017, and came into effect on 1 January 2018, available at: (www.npc.gov.cn/npc/xinwen/201706/27/content_2024513.htm).

43 Water Pollution Prevention and Control Law, Art. 5. 
protection objectives is regarded as the content of the assessment and evaluation of local governments. ${ }^{44}$ These new regulations would encourage local governments to address water pollution more effectively.

\section{Prospects and conclusion}

17. As shown above, there still remain several issues to be solved in the future. First, the relationship between MFZ and the MERL might cause confusion in practice, and needs further integration. MFZ and the MERL are two different and important marine spatial planning approaches to supporting the conservation of marine biodiversity. With the new revision of LMEP, the MERL currently has the same legal status and binding force as MFZ. ${ }^{45}$ However, these two fundamental systems were established with different objectives. MFZ aims to regulate the activities of use of marine resources, while the MERL is intended to promote marine ecological protection, and the management of these two involves different authority departments. The problems may arise when MFZ and the MERL are spatially overlapping. ${ }^{46}$ In theory, the MERL is designed to supplement MFZ, and in practice, the MERL should be the reference basis for the delineation of MFZ. The MERL should be delineated firstly to draw a boundary between exploitation and conservation to ensure the ecological security within the red line, then MFZ can be defined outside the exploitation forbidden zone. ${ }^{47}$ However, China's MFZ practice is earlier than the MERL, thus currently the delineation of the MERL is restricted by the existing MFZ which weakens the protection standards and the integrity of the MERL. In addition, it is recommended that the protection standards of the MERL should be stricter than those required for MFZ. However, the current MERL has similar management requirements as MFZ, 48 thus the objective to use the MERL to strengthen MFZ cannot be achieved.

\footnotetext{
44 Ibid, Art. 6.

45 The legal status of marine functional zone is defined by the Law of the People's Republic of China on the Administration of the Use of Sea Areas.

46 There will be spatial overlap between MFZ and the MERL in marine protected areas, important fishery areas and reserved areas.

47 Y.X. Gao, J.N. Zeng, W. Huang, et al, 'Discussion on the Relationship between Marine Functional Zoning and Marine Ecological Red Line', Ocean Development and Management (in Chinese), No.1 (2018), 33-39.

$48 \mathrm{Lu}, \mathrm{Liu}$, Xiang et.al. above n.11.
} 
Generally speaking, the MERL and MFZ at present function independently, and there is a lack of guidelines on how to manage overlapping areas. The integrity of these two systems as well as the coordination of different management departments need to be addressed in the future. Since the MERL is just at the initial stage, the technical methods for the demarcation of the MERL still need to be improved. The demarcation of the MERL is a complex process that needs to evaluate the complexity of ecosystems which includes space, time, structure, process, behavior and geometric complexity. ${ }^{49}$ However, the current methods based on the linear index model ${ }^{50}$ cannot fully reflect the complex relationship between the ecological attributes and the ecological red line zones. ${ }^{51}$ Due to the institutional reform, the supervision of the MERL is also a challenge, the SOA has organized and drafted the Provisions for the Supervision and Administration of the Marine Red Line on 2 February 2018; however, the duties of the SOA are now transferred into the Ministry of Natural Resources and the Ministry of Ecology and Environment, thus it is unclear how to implement the Provisions.

18. Second, the implementation of the marine ecological compensation and protection tax needs higher requirements on transparency and public participation. The marine ecological compensation and protection tax involves various stakeholders, across all categories (government, authority department, public and private entities, legal and natural persons). In the process of implementation, conflicts between different interests and values will inevitably occur. Therefore, the specific measures should take into account the needs and interests of all relevant stakeholders, and balance the conflicting interests. Public participation is a useful tool to ensure that the decision-making is well informed as well as to guarantee the accessibility to justice for settling environmental disputes. As

49 C. Loehle, 'Challenges of ecological complexity', Ecological Complexity, Vol.1 (2004), 3-6.

50 X.H. Liu, Q. Cheng, L. Liu, et.al. 'Study on the method of delineating the ecological red line of regional industrial layout-Developing ecology with key industries in Bohai Rim Region Assessment as an Example', 1 Papers of the 2010 Annual Meeting of the Chinese Society of Environmental Sciences (Beijing: Chinese Society of Environmental Sciences, 2010).

51 Y. Lin, J.F. Fan, Q. Wen, et.al. 'Primary exploration of ecological theories and technologies for delineation of ecological redline zones', Acta Ecologica Sinica, Vol.36, No.5 (2016), 1244-1252. 
to the protection tax, the local governments have the authority to set the tax rates, which might vary among regions. Thus, it is rational that the public should get access to the environment information and the basis on which the government sets the rates. Since the protection tax is part of local tax revenues, the public also has the right to know where the tax collections go and how the government uses them. Public participation in the protection tax can effectively supervise the government, prevent corruption and create incentives for tax payers to comply with it. As to the marine ecological compensation, when damage has occurred, the adverse impact on the marine environment associated with such damage should be timely published, and the working procedures of relevant authorities to deal with ecological restoration should be transparent. The ecological compensation is not just a punishment for the polluters but also an issue involving public interests. However, the public availability to environmental information and the management transparency with respect to ecological compensation currently does not implement well. In 2011, the Penglai 19-03 oil spill occurred, which caused pollution of more than 6,200 square kilometers of water in the Bohai Bay. ${ }^{52}$ As a result, ConocoPhillips paid 1.683 billion yuan to the SOA for marine ecological damage. ${ }^{53}$ However, the use of the compensation and the marine ecological conditions in the polluted waters were not timely made public. The public are finally aware of such information thanks to the Biodiversity Conservation and Green Development Foundation that submitted an application to SOA for information disclosure. ${ }^{54}$

52 See the Report of the Joint Investigation Team of Oil Spill Accidents in Penglai 19-3 Oilfield on the Investigation of Accidents, issued by SOA on 12 June 2012, available at: (www.chinanews.com/gn/2012/0621/3980404.shtml).

53 The SOA released on its official website a report on the investigation and handling of an oil spill in Penglai 19-3 oilfield by a joint investigation team. The report said the total value of marine ecological damage caused by the oil spill was 1.683 billion yuan, and ConocoPhillips paid a total of 1.683 billion yuan.

54 On 12 July 2015, the China Biodiversity Protection and Green Development Fund Committee filed a lawsuit with the Qingdao maritime court, requesting that court order the defendant ConocoPhillips to repair the Bohai Sea ecological environment damaged by the oil spill, and restore the Bohai Sea ecological environment to its condition before the accident. 
19. In conclusion, the current rapid economic development in China's coastal regions has placed greater pressure upon the marine environment. The new laws and regulations, though helpful, are to be tested in practice to see whether they can be implemented effectively.

This is the first public interest lawsuit in China concerning the marine environment in which a social organization was the plaintiff. Before filing the lawsuit, the China Biodiversity Protection and Green Development Fund Committee had applied to the SOA for information disclosure. 